\title{
Microbial reduction of iron and porewater biogeochemistry in acidic peatlands
}

\author{
K. Küsel ${ }^{1,2}$, M. Blöthe ${ }^{2, *}$, D. Schulz ${ }^{2}$, M. Reiche ${ }^{1}$, and H. L. Drake ${ }^{2}$ \\ ${ }^{1}$ Limnology Research Group, Friedrich Schiller University Jena, 07743 Jena, Germany \\ ${ }^{2}$ Department of Ecological Microbiology, University of Bayreuth, 95440 Bayreuth, Germany \\ *now at: Department of Geology and Geophysics, University of Wisconsin-Madison, Madison, WI 53706, USA
}

Received: 15 April 2008 - Published in Biogeosciences Discuss.: 27 May 2008

Revised: 18 September 2008 - Accepted: 22 September 2008 - Published: 12 November 2008

\begin{abstract}
Temporal drying of upper soil layers of acidic methanogenic peatlands might divert the flow of reductants from $\mathrm{CH}_{4}$ formation to other electron-accepting processes due to a renewal of alternative electron acceptors. In this study, we evaluated the in situ relevance of $\mathrm{Fe}(\mathrm{III})$-reducing microbial activities in peatlands of a forested catchment that differed in their hydrology. Intermittent seeps reduced sequentially nitrate, $\mathrm{Fe}(\mathrm{III})$, and sulfate during periods of water saturation. Due to the acidic soil conditions, released Fe(II) was transported with the groundwater flow and accumulated as Fe(III) in upper soil layers of a lowland fen apparently due to oxidation. Microbial Fe(III) reduction in the upper soil layer accounted for 26.7 and $71.6 \%$ of the anaerobic organic carbon mineralization in the intermittent seep and the lowland fen, respectively. In an upland fen not receiving exogenous $\mathrm{Fe}, \mathrm{Fe}$ (III) reduction contributed only to $6.7 \%$. Fe(II) and acetate accumulated in deeper porewater of the lowland fen with maximum concentrations of 7 and $3 \mathrm{mM}$, respectively. Both supplemental glucose and acetate stimulated the reduction of $\mathrm{Fe}(\mathrm{III})$ indicating that fermentative, incomplete, and complete oxidizers were involved in $\mathrm{Fe}$ (II) formation in the acidic fen. Amplification of DNA yielded PCR products specific for Acidiphilium-, Geobacter-, and Geothrix-, but not for Shewanella- or Anaeroromyxobacter-related sequences. Porewater biogeochemistry observed during a 3year-period suggests that increased drought periods and subsequent intensive rainfalls due to global climate change will further favor $\mathrm{Fe}(\mathrm{III})$ and sulfate as alternative electron acceptors due to the storage and enhanced re-oxidation of their reduced compounds in the soil.
\end{abstract}

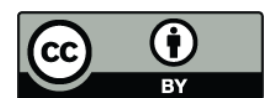

Correspondence to: K. Küsel (kirsten.kuesel@uni-jena.de)

\section{Introduction}

Acidic wetlands $(\mathrm{pH}<5.0)$ represent a vast type of northern wetlands in Eurasia and North America (Harriss et al., 1993). Waterlogging, low temperatures, and low nutrient quality of plant litter impair decomposition of plant litter, favoring the accumulation of organic carbon. Emission estimates of the greenhouse gas methane $\left(\mathrm{CH}_{4}\right)$ from wetlands range from 92 to $232 \mathrm{Tg} \mathrm{CH}_{4}$ year $^{-1}$ (Wuebbles and Hayhoe, 2002). Although rates of $\mathrm{CH}_{4}$ production were shown to be correlated with water-table depth, peat chemistry and vegetation type (Verville et al., 1998), pathways of $\mathrm{CH}_{4}$ production are still not well understood. Generally, two-thirds of the biogenic $\mathrm{CH}_{4}$ produced in wetlands originates from acetoclastic methanogenesis (Conrad, 1999). However, $\mathrm{H}_{2}-\mathrm{CO}_{2}$ appears to be a significant precursor in northern peatlands (Avery et al., 2003; Horn et al., 2003). Acetate even accumulates in some peatlands as a terminal product of anaerobic decomposition indicating that it is not the primary source of $\mathrm{CH}_{4}$ that is emitted from such habitats (Hines et al., 2001; Duddleston et al., 2002). Acetate consumption appears to occur in these peatlands after diffusion into oxic environments where it is oxidized to carbon dioxide $\left(\mathrm{CO}_{2}\right)$.

High-latitude regions are expected to experience a temperature increase as a result of global climate change, and climate models predict a decrease in annual precipitation in most European regions during the next decades (International Panel on Climate Change (IPCC), 2007). Thus, transient drying and oxidation of upper soil layers might divert the flow of reductants from $\mathrm{CH}_{4}$ formation (Blodau et al., 2004) to other electron-accepting processes due to the renewal of alternative electron acceptors. Atmospheric nitrogen and sulfate depositions might further enhance the activity of sulfate and nitrate reducers under changed climatic conditions in northern peatlands similar to other wetlands (Gauci et al., 2002; Lamers et al., 2002; Vile et al., 2003). However, addition of alternative electron acceptors to ombrotrophic bogs and minerotrophic

Published by Copernicus Publications on behalf of the European Geosciences Union. 
Table 1. Characteristics of the seep and both fens from a forested catchment ${ }^{\mathrm{a}}$.

\begin{tabular}{|c|c|c|c|c|c|c|c|c|c|c|}
\hline Field site & Vegetation & $\begin{array}{r}\text { Groundwater } \\
\text { tabledepth } \\
(\mathrm{m})\end{array}$ & Soil type & $\begin{array}{r}\text { Depth } \\
(\mathrm{cm})\end{array}$ & $\begin{array}{r}\text { Dry } \\
\text { weight } \\
(\%)\end{array}$ & $\begin{array}{r}\mathrm{pH} \\
\left(\mathrm{CaCl}_{2}\right)\end{array}$ & $\begin{array}{r}\mathrm{C}_{\text {org }} \\
(\%)\end{array}$ & $\begin{array}{r}\mathrm{N}_{\text {total }} \\
\%\end{array}$ & $\begin{array}{r}\mathrm{Fe}_{d} \\
\left(\mathrm{~g} \mathrm{~kg}^{-1}\right)^{\mathrm{b}}\end{array}$ & $\begin{array}{r}\mathrm{Fe}_{o} \\
\left(\mathrm{~g} \mathrm{~kg}^{-1}\right)^{\mathrm{c}}\end{array}$ \\
\hline \multirow{3}{*}{$\begin{array}{l}\text { Intermittent } \\
\text { seep }\end{array}$} & Sphagnum mosses, & \multirow[t]{3}{*}{0.1 -to- 1.0} & Dystric & $0-10$ & 17.8 & 3.2 & 37.2 & 2.0 & 2.1 & 2.0 \\
\hline & Vaccinium myrtilus & & Gleysol & $10-20$ & 19.5 & 3.4 & 42.9 & 2.4 & 3.6 & 3.0 \\
\hline & & & & $20-30$ & 23.5 & 3.6 & 34.7 & 1.9 & 2.7 & 2.3 \\
\hline \multirow[t]{3}{*}{ upland fen } & Sphagnum mosses, & \multirow[t]{3}{*}{0.2} & Fibric & $0-10$ & 10.6 & 4.1 & 42.4 & 1.8 & 0.5 & 0.5 \\
\hline & Carex sp., some & & Histosol & $10-20$ & 9.5 & 4.2 & 44.0 & 1.9 & 0.4 & 0.4 \\
\hline & spruce stockings & & & $20-30$ & 9.6 & 4.4 & 39.4 & 2.1 & 0.3 & 0.4 \\
\hline \multirow[t]{3}{*}{ lowland fen } & Molinia caerulea, & \multirow[t]{3}{*}{0.1} & Fibric & $0-10$ & 5.7 & 4.6 & 38.0 & 1.9 & 18.9 & 14.2 \\
\hline & Eriophorum & & Histosol & $10-20$ & 10.0 & 4.3 & 40.0 & 1.5 & 9.8 & 8.7 \\
\hline & vaginatum & & & $20-30$ & 13.6 & 4.4 & 34.3 & 1.6 & 3.4 & 2.7 \\
\hline
\end{tabular}

a Presented are the averages from duplicate soil samples.

${ }^{\mathrm{b}} \mathrm{Fe}_{d}$ refers to pedogenic Fe-oxides.

${ }^{\mathrm{c}} \mathrm{Fe}_{o}$ refers to poorly crystallized $\mathrm{Fe}$-oxides, hydroxides, and associated gels.

fens incubated in anoxic jars do not universally divert carbon and electron flow from $\mathrm{CH}_{4}$ formation (Dettling et al., 2006).

$\delta^{34} \mathrm{~S}$ values and ${ }^{35} \mathrm{~S}$-labeling patterns indicate that the dissimilatory reduction of sulfate is an ongoing process in acidic seeps and fens of a forested catchment in northern Bavaria, Germany (Lehstenbach, Fichtelgebirge) (Alewell and Giesemann, 1996; Alewell and Novak, 2001) like in peat bogs (Wieder and Lang, 1988). In minerotrophic fens which are connected to the groundwater flow, ferric iron $[\mathrm{Fe}(\mathrm{III})]$ can be another potential electron acceptor. Fe(II) concentration profiles hint to microbial $\mathrm{Fe}$ (III) reduction in $\mathrm{pH}$ neutral fens adjacent to agricultural fields (Todorova et al., 2005), and $\mathrm{Fe}$ (III) reduction appears to parallel $\mathrm{CH}_{4}$ formation in northern acidic wetlands (Metje and Frenzel, 2005). Fe(III) reduction might compete with methanogenesis for $\mathrm{H}_{2}$ or acetate (Roden and Wetzel, 2003). Most Fe(III) reducers can use one or more alternative electron acceptors (Lovley et al., 2004), which might be advantageous in upper peat layers that experience redox fluctuations due to water-table variations or oxygen release by plant roots. While Fe(III) exists predominantly in the solid phase as oxyhydroxide minerals at circumneutral $\mathrm{pH}, \mathrm{Fe}(\mathrm{III})$ is more soluble under acidic conditions (Lovley et al., 2004). However, most cultured Fe(III) reducers are neutrophiles and have only negligible capacities to reduce $\mathrm{Fe}(\mathrm{III})$ under moderately acidic ( $\mathrm{pH} \mathrm{3-6)} \mathrm{conditions.}$ Thus, we have only a marginal understanding of the flow of carbon and reductant in acidic, $\mathrm{Fe}$ (III) rich habitats and of their inherent $\mathrm{Fe}$ (III) reducing microbial communities (Vile and Wieder, 1993; Cummings et al., 2000, 2003; Blodau et al., 2002; Petrie et al., 2003; Adams et al., 2007; Blöthe et al., 2008).

The main objectives of this study were (1) to provide experimental evidence on field based data for diverted flow of reductants from $\mathrm{CH}_{4}$ formation to other electron accepting processes in upper soil layers of peatlands which differ in their hydrology, and (2) to achieve a better understanding of the flow of carbon in acidic habitats and of their inherent $\mathrm{Fe}$ (III)-reducing community.

\section{Material and methods}

\subsection{Field site description}

The sites are located in the Lehstenbach catchment (Fichtelgebirge, Northeastern Bavaria, Germany), with a highest elevation of $877 \mathrm{~m}$ a.s.l. and an area of $4.2 \mathrm{~km}^{2}$. Ninety $\%$ is covered by Norway spruce (Picea abies [L.] KARST.) of different age classes, and thirty $\%$ of the catchment soils are fens and seeps. Upland soils in the catchment have developed from weathered granitic bedrock and are predominantly Dystric Cambisols and Cambic Podzols (WRB system). The annual precipitation in the catchment varies between 900 and $1160 \mathrm{~mm} \mathrm{yr}^{-1}$ and the average annual temperature is $5^{\circ} \mathrm{C}$. The site Schlöppnerbrunnen I $\left(50^{\circ} 08^{\prime} 14^{\prime \prime} \mathrm{N}\right.$, $11^{\circ} 53^{\prime} 07^{\prime \prime} \mathrm{E}$ ) is a fen which is located in the upper part of the catchment (upland fen), dominated by Sphagnum mosses alternately covered with patches of Vaccinium myrtillus (L.), Juncus effusus (L.), Carex nigra ((L.) Reichard)), Carex rostrata (Stokes), and Carex canescens (L.) (Table 1). The yearly mean groundwater table depth approximated $0.2 \mathrm{~m}$. Some lower situated soils in the catchment Lehstenbach are only water saturated if the groundwater level increases during autumn and winter. In these seeps, represented by the site Köhlerloh (intermittent seep), the groundwater level reaches the soil surface during autumn, winter, and spring, whereas it is about 0.5 -to- $1 \mathrm{~m}$ below the surface during summer. Open areas at the seep are vegetated with Sphagnum mosses or are partly covered with dense layer of Vaccinium myrtilus. The fen Schlöppnerbrunnen II $\left(50^{\circ} 08^{\prime} 38^{\prime \prime} \mathrm{N}, 11^{\circ} 51^{\prime} 41^{\prime \prime} \mathrm{E}\right)$ is completely overgrown by Mollinia caerulea (L. Moench), 
Eriophorum vaginatum (L.), Carex canescens (L.), and Juncus effusus (L.). It is located down slope in the catchment and close to the runoff (lowland fen). The mean groundwater table approximated $0.1 \mathrm{~m}$.

Three intermittent seeps located upstream of the lowland fen were also sampled in October 2003. These seeps were covered with spruce, Vaccinium myrtillus, and some Sphagnum mosses.

\subsection{Porewater collection}

Porewater from the upper $40 \mathrm{~cm}$ of the fens site was sampled with dialysis chambers every two months during the time period from the end of July 2001 to July 2004 with an interruption during the winter months due to coverage of the catchment with snow and ice as previously reported (Schmalenberger et al., 2007). The intermittent seep was only sampled during periods of water saturation. The hot summer of 2003 lead to a drying of the topsoil of the lowland and the upland fen down to a depth of 5-to- $10 \mathrm{~cm}$.

\subsection{Anoxic soil microcosms}

For determining rates of anaerobic microbial activities, soil samples from three replicate sites and different depths (approximately $0-10,10-20$, and $20-30 \mathrm{~cm}$ ) were obtained in September 2001 in sterile airtight vessels and transported to the laboratory. Replicates were pooled and processed within $4 \mathrm{~h}$. Fourty g (wet wt) soil was placed into $125-\mathrm{ml}$ infusion flasks (Merck ABS, Dietikon, Switzerland) inside an $\mathrm{O}_{2}$-free chamber (100\% $\mathrm{N}_{2}$ gas phase). Bottles were closed with rubber stoppers and screw-cap seals, flushed with sterile argon for $15 \mathrm{~min}$, and incubated in the dark at $15^{\circ} \mathrm{C}$ with an initial overpressure of $20-25 \mathrm{kPa}$ argon at room temperature. Headspace gases were taken by sterile, argon flushed syringes from these bottles. Gas values were estimated by Henry's law and included the total amounts in both gas and liquid phases. To facilitate sampling of water soluble parameters, $40 \mathrm{ml}$ anoxic, deionized water with a $\mathrm{pH}$ of 5.0 were added to another set of soil microcosms with $40 \mathrm{~g}$ (wet wt) soil. Adjustments of $\mathrm{pH}$ were performed with sterile solutions of $10 \mathrm{~N} \mathrm{HCl}$ and $10 \mathrm{~N} \mathrm{NaOH}$. All microcosms were done in three replicates. At 8 time points, samples were taken during 15 days of incubation in the dark at $15^{\circ} \mathrm{C}$. Activity rates were calculated by linear regression analysis during the time period of linear increase of reduced compounds or linear decrease of electron acceptors.

For determining the effect of supplemental electron donors on Fe(III)-reducing activities, soil samples $(0-10 \mathrm{~cm}$ depth) were obtained from the lowland fen in March and October 2002. Thirtyfive $\mathrm{g}$ (wet wt) soil was mixed with $70 \mathrm{ml}$ anoxic, deionized water with a $\mathrm{pH}$ of 5.0 . Glucose $(2.5 \mathrm{mM})$, acetate $(2 \mathrm{mM})$, or lactate $(2 \mathrm{mM})$ was added from sterile anoxic stock solutions; $\mathrm{H}_{2}(10 \mathrm{ml})$ was added as sterile gas. At 10 time points, samples were taken during 15 days of incubation in the dark at $15^{\circ} \mathrm{C}$. $\mathrm{Fe}$ (II) formation rates were calculated by linear regression analysis during the time period of linear increase of Fe(II) (glucose, 4 days; acetate, 8 days; lactate, $\mathrm{H}_{2}$ and control 7 days).

\subsection{Enrichments of $\mathrm{Fe}(\mathrm{III})$ reducers}

Five $g$ (wet wt) soil of the lowland fen $(0-10 \mathrm{~cm})$ obtained in October 2003 was mixed with $95 \mathrm{ml}$ of dilution buffer (Küsel et al., 2001) and further diluted in a tenfold dilution series, which were used to inoculate an anoxic, undefined medium with a pH of 5.2 that was supplemented with $40 \mathrm{mM}$ amorphous ferric hydroxide $\left[\mathrm{Fe}(\mathrm{OH})_{3}\right]$ and either acetate $(5 \mathrm{mM})$ or $\mathrm{H}_{2}(10 \mathrm{ml})$ as previously described (Blöthe et al., 2008). Bromoethanesulfonate (BESA) was added $(15 \mathrm{mM})$ to inhibit methanogenesis. Tubes were incubated in the dark at $15^{\circ} \mathrm{C}$ for 3 months.

\subsection{Analytical methods}

The $\mathrm{pH}$ was measured with a U457-S7/110 combination $\mathrm{pH}$ electrode (Ingold, Steinbach, Germany). Headspace gases $\left(\mathrm{H}_{2}, \mathrm{CO}_{2}\right.$ and $\left.\mathrm{CH}_{4}\right)$ were measured with Hewlett Packard Co. (Palo Alto, CA, USA) 5890 series II gas chromatographs (Küsel and Drake, 1995). The reduction of Fe(III) was determined after acid extraction by the amount of $\mathrm{Fe}$ (II) formed in anoxic incubations. Aliquots $(0.2 \mathrm{ml})$ of the media or of the soil suspension were taken by sterile syringes and transferred to $9.8 \mathrm{ml}$ of $0.5 \mathrm{~N} \mathrm{HCl}$ and incubated for $1 \mathrm{~h}$ at room temperature (Küsel et al., 1999). Fe(II) was measured after the addition of acetate by the phenanthroline method (Tamura et al., 1974). Pedogenic iron $\left(\mathrm{Fe}_{d}\right)$ was extracted with dithionite-citrate-bicarbonate solution (Mehra and Jackson, 1960). Poorly crystallized iron oxides, hydroxides, and associated gels $\left(\mathrm{Fe}_{o}\right)$ were extracted with acidic ammonium oxalate solution (Schwertmann, 1964). Extracted Fe was measured by atomic absorption spectrometry (Unicam 939 spectrometer, ThermoNicolet GmbH, Offenbach, Germany). Short chain aliphatic acids and alcohols were determined with Hewlett-Packard 1090 series II high-performance liquid chromatographs (Küsel and Drake, 1995). The detection limits for short chain fatty acids approximated $5-10 \mu \mathrm{M}$ and of alcohols $30 \mu \mathrm{M}$ at an injection volume of $200 \mu \mathrm{l}$. Dissolved organic carbon (DOC) was analyzed with a liquiTOC (Foss-Heraeus, Hanau, Germany) with a detection limit of $50 \mu \mathrm{M} . \mathrm{NH}_{4}^{+}$and $\mathrm{NO}_{3}^{-} / \mathrm{NO}_{2}^{-}$were determined by flow injection analysis with a detection limit of $3 \mu \mathrm{M}$ (QuickChemAE, Lachat Instruments, Milwaukee, WI). $\mathrm{SO}_{4}^{2-}$ was measured by ion chromatography with a detection limit of $3 \mu \mathrm{M}$ (DX100 with AS4 A column; Dionex, Sunnyvale, CA). Sulfide was measured by the Cline procedure with a detection limit of $5 \mu \mathrm{M}$ (Cline, 1969). 
Table 2. Anaerobic activities of seep and fen soils in anoxic microcosms of September 2001.

\begin{tabular}{|c|c|c|c|c|c|c|c|c|}
\hline \multirow[t]{2}{*}{ Site } & \multirow[t]{2}{*}{$\begin{array}{r}\text { Depth } \\
\mathrm{cm}\end{array}$} & \multicolumn{5}{|c|}{$\begin{array}{l}\text { Rate of formation or consumption } \\
\left.[\text { nmol g (wet wt soil) })^{-1} \mathrm{~d}^{-1}\right]^{\mathrm{a}}\end{array}$} & \multirow[t]{2}{*}{$\begin{array}{r}\mathrm{Fe}(\mathrm{II})_{\max }^{\mathrm{b}} \\
{\left[\mu \mathrm{mol} \mathrm{g}(\text { wet wt soil })^{-1}\right]}\end{array}$} & \multirow{2}{*}{$\begin{array}{r}\text { Onset of } \mathrm{CH}_{4} \\
\text { formation } \\
(\text { days })\end{array}$} \\
\hline & & $\mathrm{NO}_{3}^{-}$ & $\mathrm{Fe}(\mathrm{II})$ & $\mathrm{SO}_{4}^{2-}$ & $\mathrm{CO}_{2}$ & $\mathrm{CH}_{4}$ & & \\
\hline \multirow[t]{3}{*}{ intermittent seep } & $0-10$ & -98.6 & 693 & -21.0 & 649 & 1.6 & 8.1 & 11 \\
\hline & 10-20 & -48.0 & 487 & 1.2 & 215 & 0 & 5.5 & n.a. ${ }^{\mathrm{c}}$ \\
\hline & $20-30$ & n.a. & 544 & 4.8 & 198 & 0 & 3.5 & n.a. \\
\hline \multirow[t]{3}{*}{ upland fen } & $0-10$ & -50.0 & 47 & -19.0 & 175 & 25 & 0.7 & 1 \\
\hline & 10-20 & n.a. & 19 & -1.1 & 121 & 63 & 0.4 & 4 \\
\hline & $20-30$ & n.a. & 38 & -0.2 & 44 & 30 & 0.4 & 4 \\
\hline \multirow[t]{3}{*}{ lowland fen } & $0-10$ & n.a. & 1177 & -3.2 & 411 & 619 & 15.8 & 0 \\
\hline & 10-20 & n.a. & 430 & -0.34 & 253 & 244 & 8.5 & 0 \\
\hline & $20-30$ & n.a. & 379 & -0.0 & 161 & 102 & 5.4 & 0 \\
\hline
\end{tabular}

a Presented is the average rate observed in triplicate microcosms.

$\mathrm{b}^{\mathrm{b}}$ Final $\mathrm{Fe}(\mathrm{II})$ concentrations after Fe(III)-reduction was completed.

${ }^{c}$ n.a. not applicable. $\mathrm{No}_{4} \mathrm{CH}_{4}$ was formed or no $\mathrm{NO}_{3}^{-}$was present

\subsection{DNA extraction, PCR amplification of 16S rRNA genes}

DNA was extracted from lowland fen soil $(0-10 \mathrm{~cm}$ depth) obtained in October 2003 and May 2007 using the MOBIO Power Soil DNA extraction kit according to manufacturer's instructions. Aliquots of DNA were PCR amplified using Bacteria domain-specific (GM3, GM4; Muyzer et al., 1995) and 16S rRNA gene primers specific for Acidiphilium (Acido594F, Acido1150R; Wulf-Durand et al., 1997), bioleaching-associated bacteria (Ferro458F/Ferro1473R; Wulf-Durand et al., 1997), Geobacter (GM3, 825R; Snoeyenbos-West et al. 2000), Geothrix (Gx182F, Gx472R; Snoeyenbos-West et al., 2000), Shewanella (Shw783F, Shw1245R; Snoeyenbos-West et al., 2000) as previously described (Blöthe et al., 2008). Anaeromyxobacter-specific PCR was performed according to the method described by Wu et al. (Ab112F, Ab227R; 2006).

\subsection{Clone library construction}

PCR amplicons produced with group-specific 16S rRNA gene primers were cloned using the pGEM®-T vector and Escherichia coli JM109 competent cells according to the manufacturer's instructions (Promega, Madison, WI USA). Clone libraries were screened by restriction fragment length analysis (RFLP) as previously described (Blöthe et al., 2008). All clones screened using RFLP were grouped into phylotypes according to RFLP banding patterns.

\subsection{Phylogenetic and statistical analyses}

Representative clones for each RFLP phylotype were sequenced bidirectionally using a Big-Dye Terminator v3.1 Cycle Sequencing kit (Applied Biosystems, Foster City, CA) on an Applied Biosystems 3100 Genetic Analyzer with Capillary Electrophoresis. Sequences were assembled using Sequencher v4.5 (Gene Codes Corp., Ann Arbor, MI) and prior to phylogenetic analysis, vector sequences flanking the $16 \mathrm{~S}$ rRNA gene inserts were removed. Previously identified sequences with high sequence similarity to the clones obtained in this study were determined using the BLAST algorithm against the GenBank database available from National Center for Biotechnology Information (NCBI) (Altschul et al., 1990). Clone sequences were checked for chimeras and aligned with reference sequences in the ARB software package as previously described (Blöthe et al., 2008). Dendrograms were constructed in the ARB software package by adding 16S rRNA sequences to the distance-matrix tree using PARSIMONY_INTERAKTIV without changing the overall tree topology (Ludwig et al., 2004). The coverage of the clone libraries were calculated (Singleton et al., 2001), and the sampling efficiency within clone libraries was assessed using Analytica Rarefaction 1.3 software (http://www.uga. edu/strata/software/) originally derived by Heck et al. (1975).

\subsection{Nucleotide sequence accession numbers}

The 16S rRNA gene sequences presented in this study have been deposited in the EMBL database under the accession numbers AM941453-AM941457 for Acidiphilium-affiliated 16S rRNA gene sequences, AM941458-AM941489 for Geobacter-affiliated 16S rRNA gene sequences, and AM941490-AM941491 for Geothrix-affiliated 16S rRNA gene sequences. 


\section{Results}

\subsection{Fe(III)-reducing activities}

The intermittent seep and the lowland fen displayed high $\mathrm{Fe}$ (II) formation rates during the first 7 days of incubation and reached high amounts of Fe(II) formed compared to the upland fen (Table 2). The lowland fen was depleted in nitrate, and consumption of sulfate started after Fe(II) formation reached the plateau (Fig. 1). However, $\mathrm{CH}_{4}$ formation paralleled $\mathrm{Fe}$ (III) reduction in all soil depths (Fig. 1, and data not shown). These parallel activities were not observed in the intermittent seep and the upland fen. The upland fen displayed higher sulfate-consuming activities than the lowland fen (Table 2). The intermittent seep showed negligible in situ methane forming activities.

The initial rate of $\mathrm{Fe}(\mathrm{II})$ formation in the topsoil of the lowland fen was even slightly higher in March 2002 [ $1840 \mathrm{nmolg}$ (wet wt soil) $\left.{ }^{-1} \mathrm{~d}^{-1}\right]$ than in September 2001 (Table 2). Apparently, the topsoil was more oxidized in March, because the initial Fe(II) concentration approximated only $1.7 \mu \mathrm{mol} \mathrm{g}$ (wet wt soil) ${ }^{-1}$ compared to $7.3 \mu \mathrm{molg}$ (wet wt soil $)^{-1}$ in September. However, both experiments yielded similar maximum concentrations of $\mathrm{Fe}(\mathrm{II})$ at the end of incubation (Figs. 1 and 2) which were equivalent to $70 \%$ of the $\mathrm{Fe}_{d}$ content of the soil.

\subsection{Source of iron in the lowland fen}

To detect the source of the high $\mathrm{Fe}_{d}$ concentrations in the lowland fen (Table 1), 3 intermittent seeps were sampled upstream of the lowland fen, and the upper 5 to $15 \mathrm{~cm}$ layer of each soil was incubated under anoxic conditions. These soils formed $\mathrm{Fe}$ (II) without delay with rates ranging from 90 to $1050 \mathrm{nmolg}$ (wet wt soil) ${ }^{-1} \mathrm{~d}^{-1}$. Two of these soils had high initial concentrations of $\mathrm{Fe}(\mathrm{II})$ indicating that $\mathrm{Fe}(\mathrm{III})$ reduction was an ongoing process in these wetland soils. The amounts of pedogenic iron $\left(\mathrm{Fe}_{d}\right)$ and oxalate extractable iron $\left(\mathrm{Fe}_{o}\right.$ in these acidic $(\mathrm{pH} 3.2)$ soils ranged from 2.3 to $13.9 \mathrm{~g} \mathrm{~kg}^{-1}$ and from 1.8 to $12.5 \mathrm{~g} \mathrm{~kg}^{-1}$, respectively.

\subsection{Porewater biogeochemistry}

Porewater depth profiles at the intermittent seep showed typical biogeochemical gradients of redox sensitive compounds indicating the sequential utilization of nitrate, Fe(III), and sometimes of sulfate with increasing soil depth during water saturated conditions between autumn (November) and early summer (June) (data not shown; Küsel and Alewell, 2004). $\mathrm{Fe}(\mathrm{II})$ reached maximum concentrations of $50 \mu \mathrm{M}$ in $25 \mathrm{~cm}$ depth. Declining sulfate gradients were only detected in early summer samplings. Formate (up to $650 \mu \mathrm{M}$ ), acetate (up to $260 \mu \mathrm{M}$ ), and lactate (up to $85 \mu \mathrm{M}$ ), but not propionate or butyrate were detected in the upper $20 \mathrm{~cm}$ of the porewater.

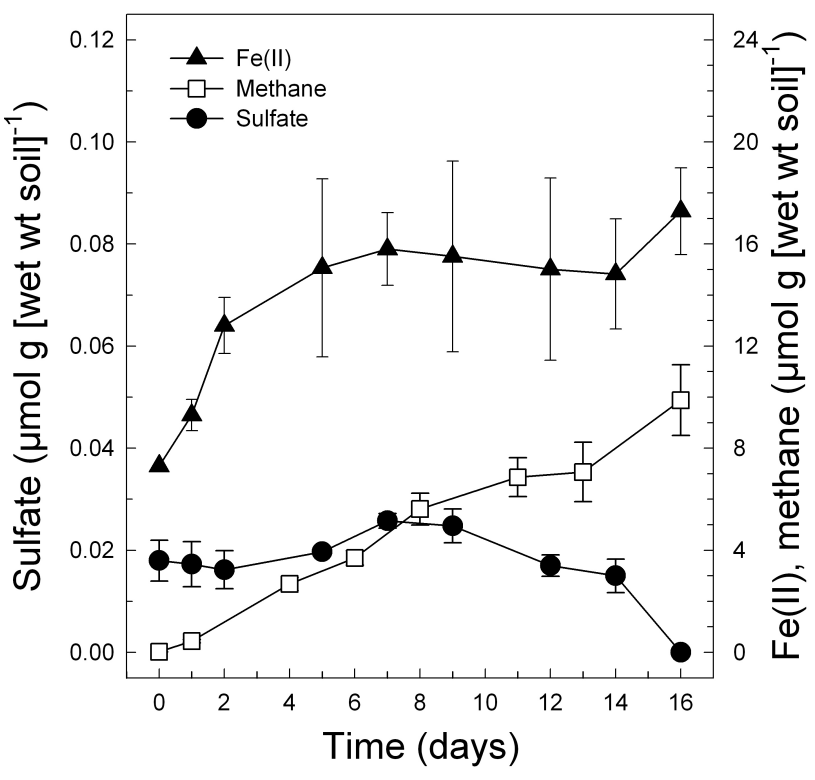

Fig. 1. Formation of $\mathrm{Fe}(\mathrm{II})$ and $\mathrm{CH}_{4}$ and consumption of sulfate in anoxic microcosms of soil obtained from the lowland fen $(0-10 \mathrm{~cm}$ depth) in September 2001. Presented are the averages \pm standard deviations of triplicates.

In general, the upland and the lowland fen showed stronger reduced conditions than the seep. Both fens showed similar qualitative biogeochemical porewater patterns during the three year sampling period. However, the lowland fen showed up to 35-fold higher concentrations of Fe(II), up to 3fold lower concentrations of sulfate, and up to 2-fold higher concentrations of $\mathrm{CH}_{4}$ in the porewater than the upland fen. The concentrations of $\mathrm{Fe}$ (II) in the lowland fen were highly variable (Figs. 3 and 4). During summer of 2001, 2002, and 2004, the depth integrated (0-to- $40 \mathrm{~cm}$ ) average Fe(II) concentrations approximated 2961, 216, and $92 \mu \mathrm{M}$. In general, maximum Fe(II) concentrations occurred below $30 \mathrm{~cm}$ depth.

In the lowland fen, the concentrations of nitrate (up to $55 \mu \mathrm{M}$ ), sulfate (up to $140 \mu \mathrm{M}$ ), and negligible concentrations of $\mathrm{Fe}(\mathrm{II})$ and ammonia indicated soil oxygenation down to a depth of $25 \mathrm{~cm}$ after the snowmelt in 2002, 2003, and 2004 (Fig. 3). Oxygenation might have occurred due to mixing of the porewater with lateral flowing, oxygenated surface water. Drying of the topsoil (upper 5-to-10 cm) occurred during the hot summer in 2003 followed by heavy rain falls prior to sampling in September. Up to $420 \mu \mathrm{M}$ sulfate (Figs. 3 and S1, http://www.biogeosciences.net/5/1537/ 2008/bg-5-1537-2008-supplement.pdf) were detected in the upper $20 \mathrm{~cm}$ of the fen soil, and Fe(II) concentrations did not exceed $30 \mu \mathrm{M}$. Fe(II) concentrations increased again in December 2003 to $370 \mu \mathrm{M}$. The concentration of sulfide never exceeded the detection limit of $5 \mu \mathrm{M}$ in the porewater.

The concentrations of short chain fatty acids detected in the porewater of the lowland fen were much higher than in 

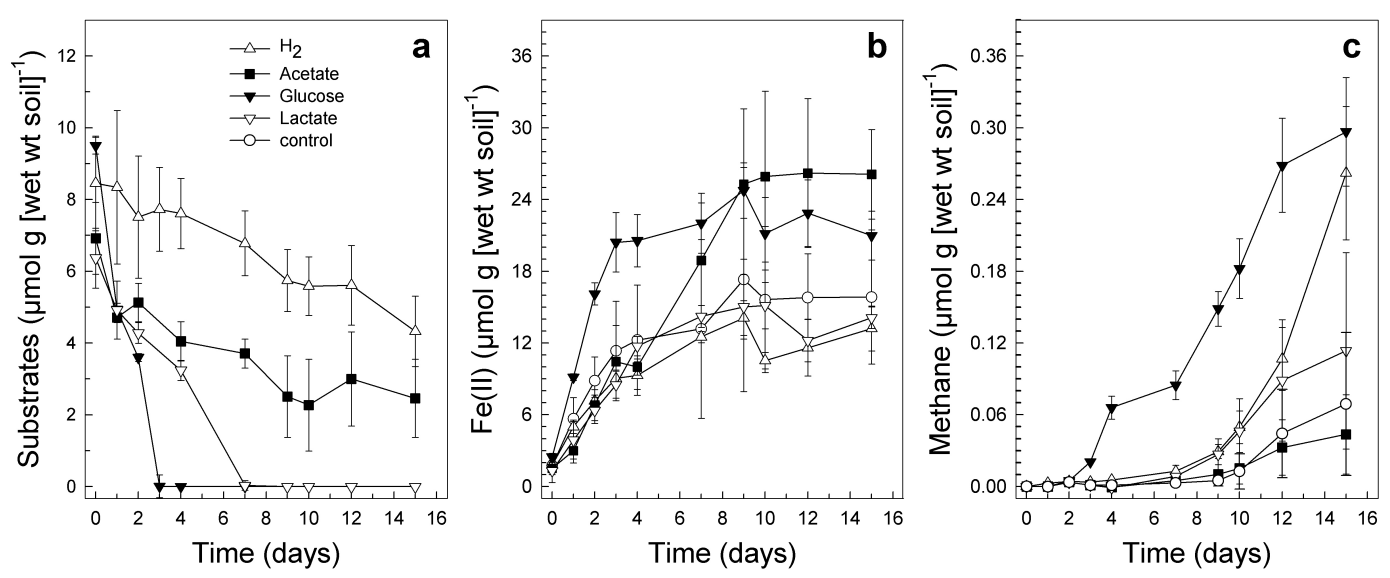

Fig. 2. Effect of the consumption of supplemental electron donors (a) on the formation of $\mathrm{Fe}(\mathrm{II})$ (b) and formation of $\mathrm{CH}_{4}(\mathbf{c})$ in anoxic microcosms of soil obtained from the lowland fen $(0-10 \mathrm{~cm})$ in March, 2002. Presented are the averages \pm standard deviations of triplicates.

the upland fen. In general, concentrations increased with increasing soil depth (Fig. 3). Depth integrated average concentrations in the lowland fen approximated 82, 56, 44, 15, and $4 \mu \mathrm{M}$ during 2001 to 2004 for acetate, formate, lactate, propionate, and butyrate, respectively. Highest concentrations were detected in November 2001 and December 2002, where concentrations of acetate, propionate, butyrate, and lactate reached up to $3160,1600,100$, and $95 \mu \mathrm{M}$ in the porewater (Figs. 3 and 4b, and data not shown). In contrast, maximum concentrations of formate occurred in April 2002 (Fig. 3). Ethanol was never detected. Porewater $\mathrm{pH}$ did not decrease in the presence of high concentrations of short chain fatty acids. Acetate concentrations were positively correlated with $\mathrm{Fe}(\mathrm{II})\left(R^{2}=0.75\right.$; Fig. 4).

\subsection{Effect of supplemental electron donors on Fe(III)- reducing activities}

Since the high concentrations of acetate observed might be derived from fermentation, glucose and typical fermentative products were supplemented to lowland fen soil. The initial rate of $\mathrm{Fe}$ (II) formation was enhanced from $1.84 \mu \mathrm{mol} \mathrm{g}$ (wet wt soil $)^{-1} \mathrm{~d}^{-1}$ to $6.08 \mu \mathrm{molg}$ (wet wt soil) $)^{-1} \mathrm{~d}^{-1}$ by supplemental glucose, but not with supplemental acetate, lactate, and $\mathrm{H}_{2}$. However, a secondary $\mathrm{Fe}(\mathrm{II})$-forming increase occurred after 4 days in acetate microcosms (Fig. 2). Glucose and acetate supplemented microcosms yielded higher maximum $\mathrm{Fe}$ (II) concentrations of 24.7 and $26.2 \mu \mathrm{mol} \mathrm{g}$ (wet wt soil) ${ }^{-1}$ compared to $15.4 \mu \mathrm{mol} \mathrm{g}$ (wet wt soil) ${ }^{-1}$ of the control.

Glucose was rapidly consumed within 3 days (Fig. 2a) and yielded $\mathrm{CO}_{2}$ and acetate as end products, and $\mathrm{H}_{2}$ and ethanol as transient products (Fig. S2, http://www.biogeosciences. net/5/1537/2008/bg-5-1537-2008-supplement.pdf). Supplemental lactate yielded acetate as main product. Both acetate and $\mathrm{H}_{2}$ were not completely consumed during 15 days of incubation. $\mathrm{H}_{2}$ but not acetate stimulated the formation of $\mathrm{CH}_{4}$ (Fig. 2c). Microcosms supplemented with either acetate, $\mathrm{H}_{2}$ or glucose with soil obtained in October 2002 yielded similar results (data not shown). Formate was detected as a small transient product only in glucose amended microcosms of October 2002.

\subsection{Molecular detection of $\mathrm{Fe}(\mathrm{III})$ reducers}

PCR with lowland fen soil yielded products with 16S rRNA primers specific for acidophiles belonging to Acidiphilium and for neutrophiles belonging to Geobacter or Geothrix. No PCR products were obtained with a primer set specific for bioleaching-associated bacteria, Shewanella or Anaeromyxobacter. PCR products with Geobacter specific primers were detected in enrichments obtained from a $10^{-3}$ soil dilution transferred to mineral medium at $\mathrm{pH} 5.5$ supplemented with $40 \mathrm{mM}$ amorphous ferric hydroxide $\left[\mathrm{Fe}(\mathrm{OH})_{3}\right]$ and $5 \mathrm{mM}$ acetate or $\mathrm{H}_{2}$. PCR products with Acidiphilium specific primers were detected up to a $10^{-3}$ soil dilution enrichment amended with acetate but not with $\mathrm{H}_{2}$, and PCR products with Geothrix specific primers were detected only in $10^{-1}$ soil dilution enrichments. Screening of $16 \mathrm{~S}$ rRNA gene clones by RFLP revealed that all phylotypes detected in the enrichments also occurred in the fen soil.

A total of 45 Acidiphilium-16S rRNA gene clones were screened by RFLP, and 13 different phylotypes could be differentiated. Comparative sequence analyses indicated that 5 phylotypes were $95 \%$ similar to cultured Acidiphilium or Acidosphaera species. Clones were most closely related (96-98\% sequence similarity) to a forest soil or sphagnum peat bog clone (Fig. 5). With the primer pair specific for Geothrix, 20 clones were obtained, but only 2 different phylotypes were obtained with a $96-97 \%$ sequence similarity to Geothrix-related sequences. 

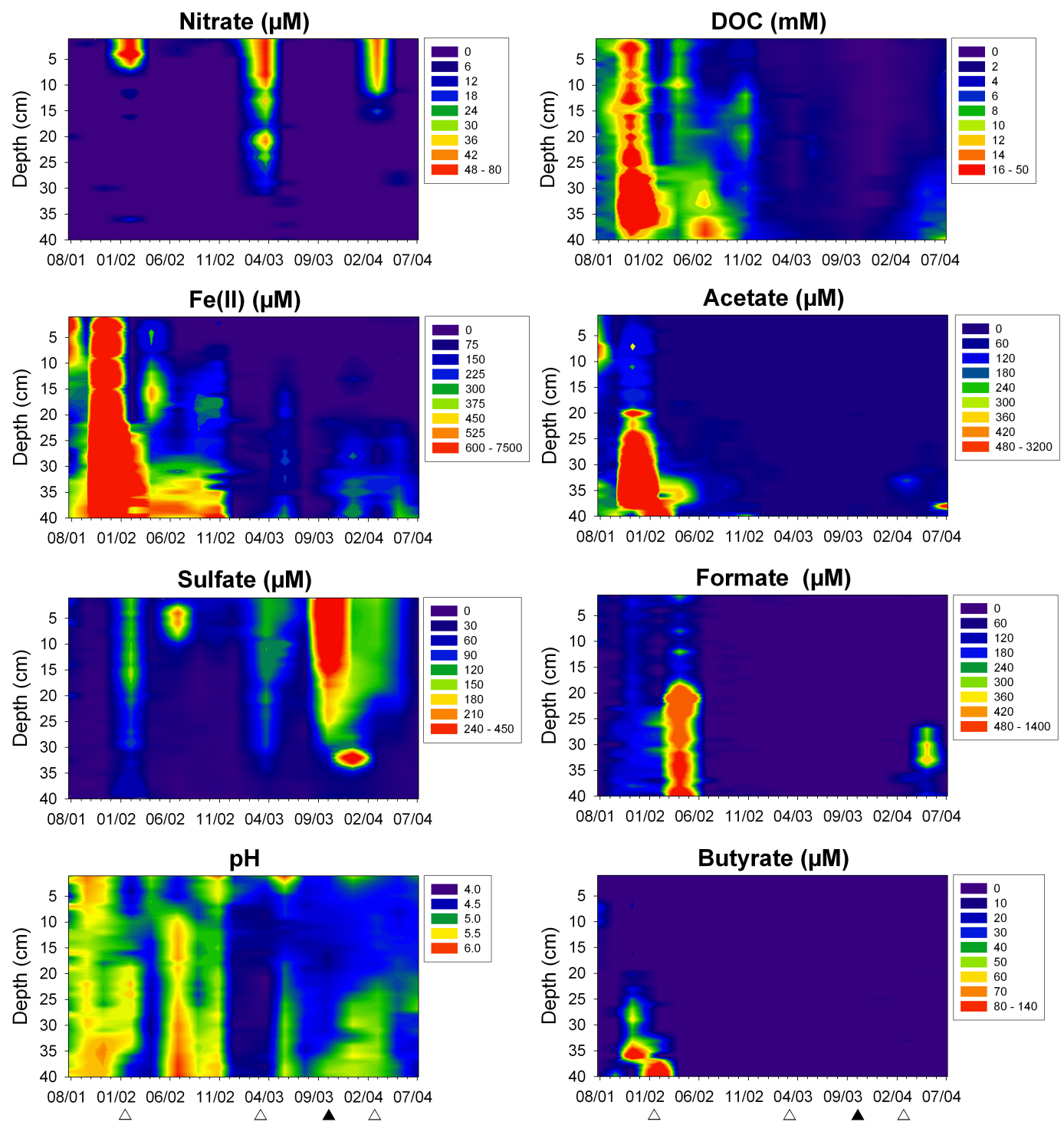

Fig. 3. Porewater concentrations of nitrate, $\mathrm{Fe}(\mathrm{II})$, sulfate, $\mathrm{pH}, \mathrm{DOC}$, acetate, formate, and buturate in the lowland fen sampled during end of July 2001 to July 2004. Please note that the upper concentrations were combined in a range for better visualization of low concentrations. White triangles below the $\mathrm{x}$-axis flag the snow melt events, the black triangle flags the summer drought followed by a heavy rain fall in September 2003.

With the primer pair specific for Geobacter, a total of 83 clones were obtained and 40 different phylotypes were obtained. A number of non-Geobacteraceae sequences and chimeras between Geobacteraceae and non-Geobacteraceae were detected. Comparative sequence analysis revealed that 34 of the 40 sequences retrieved showed high sequence identity to Geobacteraceae sequences (Fig. 6); one was related to Geobacter chapellii str. 172 (96\% sequence similarity), three were related to Geobacter bemidjiensis and Geobacter bremensis (94-96\% sequence similarity). Many sequences were similar to Pelobacter spp. (94-97\%). Acidiphilium and Geobacter specific 16S rRNA gene clone libraries showed coverages of 57 and $35 \%$, respectively.

\section{Discussion}

\subsection{Mobilization and oxidation of Fe(II) in the catchment}

At the upland fen, porewater concentrations of $\mathrm{Fe}(\mathrm{II})$ were low, similar to oligotrophic ombrogenic peatlands that receive most of their iron from atmospheric deposition. The low $\mathrm{Fe}(\mathrm{III})$ reduction rates corresponded to the low amounts of oxalate extractable $\mathrm{Fe}$ (III) oxides present in the upland fen and indicated that $\mathrm{Fe}(\mathrm{III})$ reduction was of minor significance for the oxidation of carbon in this fen similar to other northern peatlands (Blodau et al., 2002). Porewater profiles of $\mathrm{Fe}(\mathrm{II})$ and sulfate in the intermittent seep were similar to $\mathrm{pH}$ 


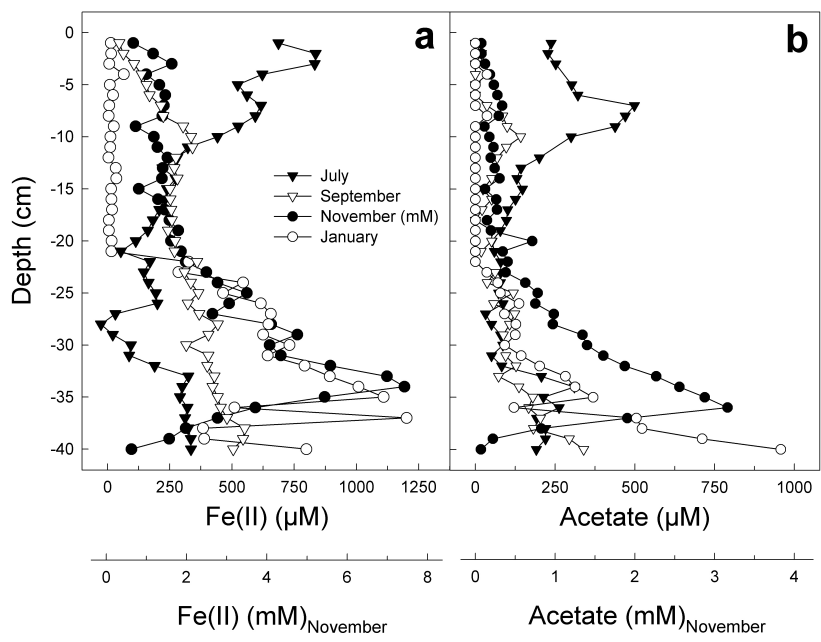

Fig. 4. Detailed porewater depth profiles of $\mathrm{Fe}(\mathrm{II})$ (a) and acetate (b) in the lowland fen sampled in July, September, and November 2001, and in January 2002.

neutral fens (Todorova et al., 2005; Dettling et al., 2006) or other wetlands (Roden and Wetzel, 2003). The high Fe(II) formation rate at the seep suggested a mobilization of $\mathrm{Fe}$ (II) during waterlogging from autumn to spring. Fe(II) was also spontaneously formed in other waterlogged seeps sampled upstream of the lowland fen further strengthening the suggestion that $\mathrm{Fe}(\mathrm{III})$ reduction is an ongoing process in many seeps of this catchment. The lowland fen is connected to a shallow groundwater layer and receives water from these intermittent seeps and fens located in the north-east of the Lehstenbach catchment (Küsel and Alewell, 2004). Due to the acidic ( $\mathrm{pH}$ 3.1) soil conditions of most seeps, the majority of the reductive dissolved $\mathrm{Fe}(\mathrm{II})$ will not adsorb to the solid phase and move with the groundwater flow. Indeed, concentrations of $\mathrm{Fe}$ (II) in a nearby groundwater well range from 9-to-143 $\mu \mathrm{M}$ (Küsel and Alewell, 2004). Thus, the lowland fen appears to receive continuously anoxic Fe(II)-rich groundwater. The high accumulation of iron in the upper soil of the lowland fen might have resulted from the oxidation of $\mathrm{Fe}(\mathrm{II})$ in oxidized peat surface layers. The high $\mathrm{Fe}_{o} / \mathrm{Fe}_{d}$ ratios $(\sim 0.8)$ (Table 1$)$ suggest that $\mathrm{Fe}(\mathrm{IIII})$ precipitated as amorphous oxides or as organic matter complexes. Microbial Fe(II) oxidation might yield colloidal or dissolved forms of $\mathrm{Fe}(\mathrm{III})$ readily available for microbial reduction (Roden et al., 2004). The high mean DOC concentration $\left(77 \mathrm{mg} \mathrm{L}^{-1}\right)$ in the porewater would further favor Fe(III) reduction, because humic compounds can serve as electron shuttles between $\mathrm{Fe}$ (III) reducers and surface-bound $\mathrm{Fe}(\mathrm{III})$ sterically not accesible to microorganisms (Lovley et al., 2004).

\subsection{In situ relevance of Fe(III)-reducing activities}

According to the 1:4 ratio of $\mathrm{CO}_{2}$ production to $\mathrm{Fe}$ (III) reduction (Roden and Wetzel, 1996), microbial Fe(III) reduction in the most active upper soil layer $(0-10 \mathrm{~cm})$ accounted for 26.7, 6.7, and $71.6 \%$ of the anaerobic organic carbon mineralization in the intermittent seep, the upland, and the lowland fen, respectively. In rhizosphere and unvegetated wetland sediments $\mathrm{Fe}$ (III) reduction accounts for approximately 65 and $40 \%$ of carbon mineralization (Roden and Wetzel, 1996). Thus, Fe(III) reduction can substantially contribute to carbon mineralization also in peatlands and reduce $\mathrm{CH}_{4}$ emissions. The lowland fen showed sequential $\mathrm{Fe}(\mathrm{III})$-reducing and sulfate-reducing activities but concomitant $\mathrm{Fe}$ (III)-reducing and methanogenic activities (Fig. 1). Overlapping or concomitant Fe(III)-reducing and methanogenic activities were not observed in soil samples obtained after the snow melts indicating that prolonged anoxic or reduced conditions in the fen were necessary for the establishment of methanogenic activities. Short-term oxygenation of reduced surface soil during summer that leads to a rapid renewal of the $\mathrm{Fe}(\mathrm{III})$ pool might yield a partial shift of the electron flow from $\mathrm{CO}_{2}$ to $\mathrm{Fe}$ (III) by methanogens and help to explain concomitant reduction processes in peatlands (Dettling et al., 2006; Metje and Frenzel, 2005; Paul et al., 2006) or in rice paddy soils after drainage (Krüger et al., 2001). The ability of some methanogens to interact with extracellular quinones, humic acids, and Fe(III) oxides has raised the possibility that methanogens contribute to Fe(III) and humic acid reduction (Bond and Lovley, 2002; van Bodegom et al., 2004). Concomitant activities can be also explained by the use of non-competetive substrates. Concomitant or reversed $\mathrm{Fe}$ (III) and sulfate reduction is reported from other fens (Todorova et al., 2005). It was suggested that concomitant reduction processes are due to the presence of more crystalline Fe(III) oxides like hematite or goethite in the soil (Postma and Jakobsen, 1996), which are reduced at lower redox potentials (Straub et al., 2001) than sulfate or $\mathrm{CO}_{2}$ (Zehnder and Stumm, 1988). However, the high $\mathrm{Fe}_{o} / \mathrm{Fe}_{d}$ ratios in the top soil hint to amorphous, easily reducible $\mathrm{Fe}(\mathrm{III})$ oxides.

\subsection{Accumulation of acetate}

High short chain fatty acid and high Fe(II) concentrations were detected in deeper soil of the lowland fen during autumn to winter in 2001/2002 and 2002/2003 with maximum concentration of 3 and $7 \mathrm{mM}$ for acetate and $\mathrm{Fe}(\mathrm{II})$, respectively. The high $\mathrm{Fe}(\mathrm{II})$ concentrations in this depth were surprising due to the relatively low amounts of iron in the solid phase. However, porewater biogeochemical gradients in fens are not only based on diffusion like in lake sediments. We can not rule out that a part of the $\mathrm{Fe}$ (II) was transported with the groundwater flow. Acetate could have been produced by fermentors using plant polysaccarides from dead 


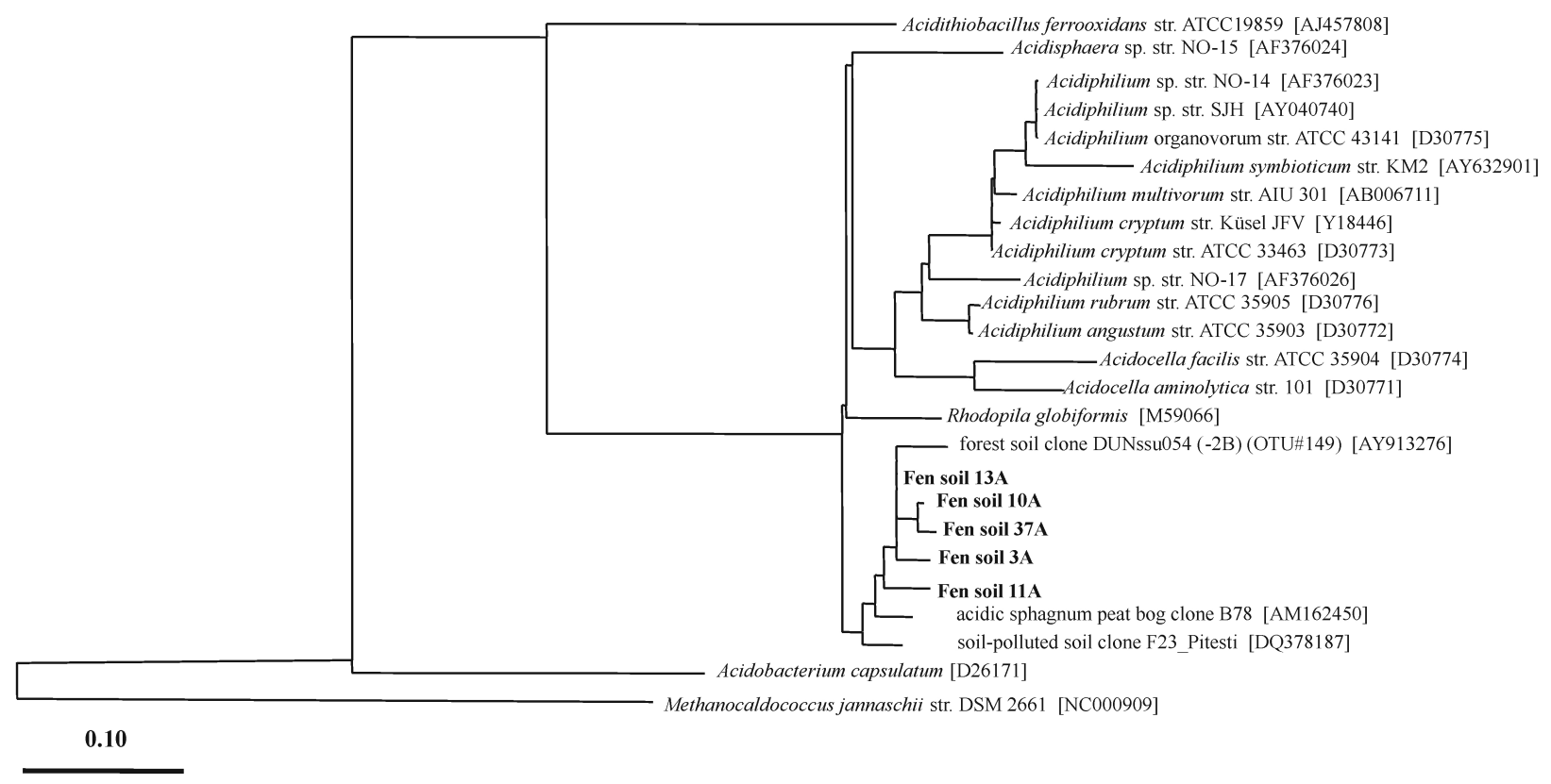

Fig. 5. Phylogenetic tree showing the relative positions of Acidiphilium-affiliated 16S rRNA gene sequences derived from the lowland fen soil $(0-10 \mathrm{~cm})$ obtained in October 2003. Sequences were added to the existing tree without changing the overall tree topology by using the ARB treeing tool PARSIMONY_INTERAKTIV. Names and accession numbers (between bracktes) for closest relatives 16S rRNA gene sequences are given. The bar indicates $10 \%$ sequence divergence.

root material. Accumulation of acetate up to $1.2 \mathrm{mM}$ is reported from bogs in Michigan or Ontario (Shannon and White, 1996; Blodau et al., 2002) and appears to be due to the absence of acetoclastic methanogenesis (Shannon and White, 1996; Hines et al., 2001). Temporal acetate accumulations might characterize fens and bogs as habitats with specific qualities. The decoupling of methanogenesis from carbon flow might be due to the direct inhibition of accumulated acetate on methanogens, because acetic acid can penetrate through the cell membrane and act as decoupler of the proton motive force under acidic conditions (Williams and Crawford, 1984; Goodwin and Zeikus, 1987) or due to transport and thermodynamic constraints (Beer and Blodau, 2007).

The positive correlation of acetate and $\mathrm{Fe}(\mathrm{II})$ in the lowland fen porewater during the 3-year-period (Figs. 3 and 4) suggests either a formation of acetate by incomplete oxidizing $\mathrm{Fe}(\mathrm{III})$ reducers or an accumulation of acetate after depletion of the $\mathrm{Fe}(\mathrm{III})$ pool by complete acetate-oxidizing $\mathrm{Fe}$ (III) reducers. Cultured Geobacter species, which were most closely related to clone sequences retrieved from this fen, like G. chapellii, G. bemidjiensis, and G. bremensis are complete oxidizers (Lovley et al., 2004). In contrast, the also closely related Pelobacter venetianus is an incomplete oxidizer. The low or negligible concentrations of acetate in upper soil suggests oxidation of acetate to $\mathrm{CO}_{2}$ via aerobic respiration, other oxidative microbial processes or syntrophic oxidation of acetate to $\mathrm{CO}_{2}$ by the concerted ac- tivity of acetate-oxidizing anaerobes and hydrogenotrophic methanogens (Horn et al., 2003; Metje and Frenzel, 2007).

\subsection{Fe(III)-reducing microbial communities of acidic habi- tats}

Due to our limited knowledge about $\mathrm{Fe}(\mathrm{III})$ reduction in moderate acidic habitats, phylogenetic analyses of $\mathrm{Fe}$ (III) reducers based on known 16S rRNA gene sequences are severely limited, and we might miss important genera. Phylotypes related to cultured Acidiphilium or Acidisphaera species were detected in the lowland fen similar to slightly acidic coal mining lake sediments (Blöthe et al., 2008). Most $\mathrm{Fe}(\mathrm{III})$-reducing prokaryotes cultured to date are either neutrophilic or acidophilic and have only minor capacities to reduce $\mathrm{Fe}(\mathrm{III})$ at in a $\mathrm{pH}$ range from 4 to 6 . The acidophilic Acidiphilium cryptum (ATCC 33463) can reduce only small amounts of solid phase $\mathrm{Fe}(\mathrm{III})$ at $\mathrm{pH} 5$ (Bilgin et al., 2004). Geobacter sp. CdA-3 that was isolated from a mining-impacted sediment can reduce $\mathrm{Fe}(\mathrm{III})$ at a $\mathrm{pH}$ range from 5.5 to 8.1 (Cummings et al., 2000), and G. bremensis can reduce $\mathrm{Fe}(\mathrm{III})$ down to $\mathrm{pH} 5$ (Straub and Bucholz-Cleven, 2001). Members of the $\delta$-Proteobacteria subdivision, including Geobacter- and Anaeromyxobacter dehalogenans-related sequences seem to be important metalreducing organisms in biostimulated acidic subsurface sediments (North et al., 2004) However, other studies with acidic uranium contaminated sediments demonstrate that 


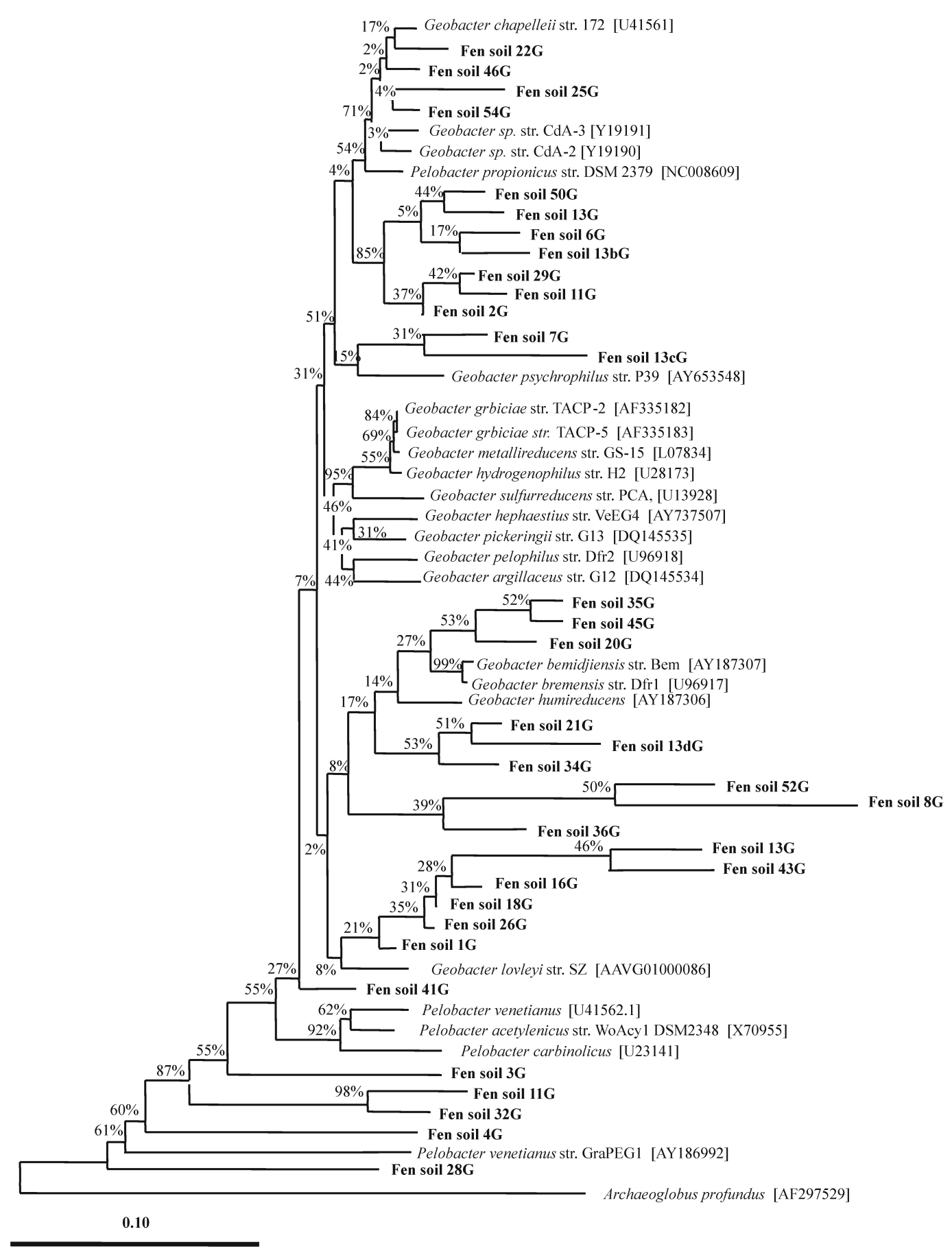

Fig. 6. Phylogenetic tree showing the relative positions of the Geobacter-affiliated 16S rRNA gene sequences derived from the lowland fen soil $(0-10 \mathrm{~cm})$ obtained in October 2003 as inferred by Parsimony method. Bootstrap values for a total of 100 replicates are shown at the nodes. Names and accession numbers (between bracktes) for all 16S rRNA gene sequences used for comparsion are given. The bar indicates $10 \%$ sequence divergence.

Geobacteraceae dominate only in sediment enrichment cultures incubated under neutral $\mathrm{pH}$ conditions (Petrie et al., 2003). Surprisingly, no PCR products of Anaeromyxobacter, or Shewanella related species were obtained from the lowland fen, although microorganisms from these genera are common to various metal-reducing environments. Recently it was shown that Acidobacterium capsulatum is capable of $\mathrm{Fe}(\mathrm{III})$ reduction in a pH range of 2 to 5 (Blöthe et al., 2008) 
and that the potential for dissimilatory $\mathrm{Fe}(\mathrm{III})$ reduction is widespread among acidophilic heterotrophic bacteria (Coupland and Johnson, 2008). Acidobacteria are present in peatlands (Dedysh et al., 2006) and have been detected also in the upland fen of this catchment (Schmalenberger et al., 2008). Thus, results from phylogenetic analyses in this investigation provide an incomplete picture.

\section{Conclusions}

Our field based experimental results corroborate the hypotheses that a decrease in annual summer precipitation in most northern European regions as a result of global climate change (IPCC 2007) will shift the electron flow away from methanogenesis to alternative anaerobic processes in peatlands. Drying of the top soil down to $10 \mathrm{~cm}$ depth during the hot summer 2003 followed by heavy rain falls in September lead to the appearance of sulfate in the porewater and a renewal of $\mathrm{Fe}$ (III) which favored the subsequent $\mathrm{Fe}$ (III)- and sulfate-reducing activities. Drying and rewetting of the top soil 2003 yielded even higher porewater sulfate concentrations in the lowland fen than in the upland fen despite the average 3-fold lower sulfate concentrations in the lowland fen (Fig. S1). The higher release of sulfate might be due to differences in the reduced sulfur pools, which were subjected to oxidation. The Fe-rich lowland fen contains higher contents of acid volatile sulfur (AVS, i.e. amorphous FeS) and total reduced inorganic sulfur (TRIS, i.e. amorphous $\mathrm{FeS}, \mathrm{S}^{0}$, and $\mathrm{FeS}_{2}$ ) (Loy et al., 2004) but lower contents of organic sulfur compared to the upland fen (Paul et al., 2006). Synchrotronbased X-ray spectromicroscopy revealed that the fraction of organic reduced sulfur of these fens is more stable under alternating reduction-oxidation processes than the $\mathrm{FeS}$ or $\mathrm{FeS}_{2}$ pool (Prietzel, personal communication), similar to results obtained with chemical S fractionations in peat bogs (Wieder and Lang, 1988; Wieder et al., 1990). Thus, the presence of $\mathrm{Fe}(\mathrm{II})$ seemed to affect both the storage and mobilization of sulphur. An increase of extreme weather conditions like summer droughts and heavy rainfall events during the next decades will amplify the importance of iron for biogeochemical processes in iron-rich peatlands.

Acknowledgements. The authors thank Sonja Trenz, Ines Pöhler, and Anita Gößner for technical assistance, and Gunnar Lischeid and Christine Alewell for helpful discussions. Support of this study was provided by the German Ministry of Education and Research (BEO 51-0339476C) and the German Research Foundation (DFG: KU 1367/1-2; KU 1367/4-1, which is part of the research group FOR 562 "Dynamics of soil processes under extreme meteorological boundary conditions").

Edited by: T. J. Battin

\section{References}

Adams, L. K., Boothman, C., and Lloyd, J. R.: Identification and characterization of a novel acidotolerant $\mathrm{Fe}(\mathrm{III})$-reducing bacterium from a 3000-year-old acidc rock drainage site, FEMS Microbiol. Lett., 268, 151-157, 2007.

Alewell, C. and Gehre, M.: Patterns of stable S isotopes in a forested catchment as indicators for biological $\mathrm{S}$ turnover, Biogeochemistry, 47, 319-333, 1999.

Alewell, C. and Giesemann, A.: Sulfate reduction in a forested catchment as indicated by $\delta^{34} \mathrm{~S}$ values of sulfate in soil solutions and runoff, Isot. Environ. Healt. S., 32, 203-210, 1996.

Alewell, C. and Novak, M.: Spotting zones of dissimilatory sulfate reduction in a forested catchment: The ${ }^{34} \mathrm{~S}-{ }^{35} \mathrm{~S}$ approach, Environ. Pollut., 112, 369-377, 2001.

Altschul, S. F., Gish, W., Miller, W., Myers, E. W., and Lipman, J. D.: Basic local alignment search tool, J. Mol. Biol., 215, 403410, 1990.

Avery, G. B., Shannon, R. D., White, J. R., Martens, C. S., and Alperin, M. J.: Controls on methane production in a tidal freshwater estuary and a peatland: methane production via acetate fermentation and $\mathrm{CO}_{2}$ reduction, Biogeochemistry, 62, 19-37, 2003.

Beer, J. and Blodau, C.: Transport and thermodynamics constrain belowground carbon turnover in a northern peatland, Geochim. Cosmochim. Ac., 71, 2989-3002, 2007.

Bilgin, A. A., Silverstein, J. A., and Jenkins, J. D.: Iron respiration by Acidiphilium cryptum at pH 5, FEMS Microbiol. Ecol., 49, 137-143, 2004.

Blodau, C., Roehm, C., and Moore, T. R.: Iron, sulfur, and dissolved carbon dynamics in a northern peatland, Arch. Hydrobiol., 154, 561-583, 2002.

Blodau, C., Basiliko, N., and Moore, T. R.: Carbon turnover in peatland mesocosm exposed to different water table levels, Biogeochemistry, 67, 331-351, 2004.

Blöthe, M., Akob, D. M., Kostka, J. E., Göschel, K., Drake, H. L., and Küsel, K.: pH gradient-induced heterogeneity of Fe(III)reducing microorganisms in coal mining-associated lake sediments, Appl. Environ. Microb., 74, 1019-1029, 2008.

Bond, D. R. and Lovley, D. R.: Reduction of Fe(III) oxide by methanogens in the presence and absence of extracellular quinones, Environ. Microbiol., 4, 115-124, 2002.

Cline, J. D.: Spectrophotometric determination of hydrogen sulfide in natural waters, Limnol. Oceanogr., 14, 454-458, 1969.

Conrad, R.: Contribution of hydrogen to methane production and control of hydrogen concentrations in methanogenic soils and sediments, FEMS Microbiol. Ecol., 28, 193-202, 1999.

Coupland, K. and Johnson, D. B.: Evidence that the potential for dissimilatory ferric iron reduction is widespread among acidophilic heterotrophic bacteria, FEMS Microbiol. Lett., 279, 3035, 2008.

Cummings, D. E., March, A. W., Bostick, B., Spring, S., Caccavo Jr., F., and Rosenzweig, R. F.: Evidence for microbial $\mathrm{Fe}(\mathrm{III})$-reduction in anoxic, mining-impacted lake sediments (Lake Coeur d'Alene, Idaho), Appl. Environ. Microb., 66, 154 162, 2000.

Cummings, D. E., Snoeyenbos-West, O. L., Newby, D. T., Niggemyer, A. M., Lovley, D. R., Achenbach, A., and Rosenzweig, R. F.: Diversity of Geobacteraceae species inhabiting metalpolluted freshwater lake sediments ascertained by $16 \mathrm{~S}$ rDNA 
analyses, Microb. Ecol., 46, 257-269, 2003.

Dedysh, S. N., Pankratov, T. A., Belova, S. E., Kulichevskaya, I. S., and Liesack, W.: Phylogenetic analysis and in situ identification of bacteria community composition in an acidic Sphagnum peat bog, Appl. Environ. Microb., 72, 2110-2117, 2006.

Dettling, M. D., Yavitt, J. B., and Zinder, S. H.: Control of organic carbon mineralization by alternative electron acceptors in four peatlands, central New York State, USA, Wetlands, 4, 917-927, 2006.

Duddleston, K. N., Kinney, M. A., Kiene, R. P., and Hines, M. E.: Anaerobic microbial biogeochemistry in a northern bog: acetate as a dominant metabolic end product, Global Biogeochem. Cy., 16, 1063, doi:10.1029/2001GB001402, 2002.

Gauci, V., Dise, N., and Fowler, D.: Controls on suppression of methane flux from a peat bog subjected to simulated acid rain sulfate deposition, Global Biogeochem. Cy., 16(1), 1004, doi:10.1029/2000GB001370, 2002.

Goodwin, S. and Zeikus, J.G.: Ecophysiological adaptations of anaerobic bacteria to low $\mathrm{pH}$ : analysis of anaerobic digestion in acidic bog sediments, Appl. Environ. Microb., 53, 57-64, 1987.

Harriss, R., Bartlett, K., Frolking, S., and Crill, P.: Methane emissions from northern high-latitude wetlands, in: Biogeochemistry of Global Change. Radiatively Active Trace Gases, edited by: Oremland, R. S., Chapman \& Hall, New York, 449-486, 1993.

Heck, K. L., van Belle, G., and Simberloff, D.: Explicit calculation of the rarefaction diversity measurement and the determination of sufficient sample size, Ecology, 56, 459-1461, 1975.

Hines, M. E., Duddleston, K. N., and Kiene, R. P.: Carbon fow to acetate and $\mathrm{C} 1$ compounds in northern wetlands, Geophys. Res. Lett., 28, 4251-4254, 2001.

Horn, M. A., Matthies, C., Küsel, K., Schramm, A., and Drake, H. L.: Hydrogenotrophic methanogenesis by moderately acidtolerant methanogens of a methane-emitting acidic peat, Appl. Environ. Microb., 69, 74-83, 2003.

International Panel on Climate Change (IPCC): Climate change 2007: Synthesis report. Contribution of working groups I, II and III to the fourth assessment report of the Intergovernmental Panel on Climate Change (core writing team), edited by: Pachauri, R. K. and Reisinger, A., IPCC, Geneva, Switzerland, p. 104, 2007.

Krüger, M., Frenzel., P., and Conrad, R.: Microbial processes influencing methane emission from rice fields, Global Change Biol., 7, 49-63, 2001.

Küsel, K. and Alewell, C.: Riparian zones in a forested catchment: hot spots for microbial reductive processes, in: Biogeochemistry of two German forested catchments in a changing environment, edited by: Matzner, E., Ecol. Stud. 172, Springer-Verlag, 377395, 2004.

Küsel, K., Dorsch, T., Acker, G., and Stackebrandt, E.: Microbial reduction of $\mathrm{Fe}(\mathrm{III})$ in acidic sediments: Isolation of Acidiphilium cryptum JF-5 capable of coupling the reduction of $\mathrm{Fe}(\mathrm{III})$ to the oxidation of glucose, Appl. Environ. Microb., 65, 3633-3640, 1999.

Küsel, K., Roth, U., Trinkwalter, T., and Peiffer, S.: Effect of pH on the anaerobic microbial cycling of sulfur in mining-impacted freswater lake sediments, Environ. Exp. Bot., 46, 213-223, 2001.

Küsel, K. and Drake, H. L.: Effects of environmental parameters on the formation and turnover of acetate by forest soils, Appl. Environ. Microb., 61, 3667-3675, 1995.
Lamers, L. P. M., Smolders, A. J. P., and Roelofs, J. G. M.: The restoration of fens in the Netherlands, in: Ecological restoration of aquatic and semi-aquatic ecosystems in the Netherlands (NW Europe), edited by: Nienhuis, P. H. and Gulati, R. D., Hydrobiologia, 478, Kluver Academic Publishers, Netherlands, 107-130, 2002.

Lovley, D. R., Holmes, D. E., and Nevin, K. P.: Dissimilatory $\mathrm{Fe}(\mathrm{III})$ and $\mathrm{Mn}(\mathrm{IV})$ reduction, Adv. Microb. Physiol., 49, 212286, 2004.

Loy, A., Küsel, K., Lehner, A., Klein, M., Drake, H. L., and Wagner, M.: Microarray and functional gene analyses of sulfate-reducing prokaryotes in low sulfate, acidic fens reveal co-occurrence of recognized genera and novel lineages, Appl. Environ. Microb., 70, 6998-7009, 2004.

Ludwig, W., Strunk, O., Westram, R., Richter, L., Meier, H., Yadhukumar, Buchner, A., Lai, T., Steppi, S., Jobb, G., Förster, W., Brettske, I., Gerber, S., Ginhart, A. W., Gross, O., Grumann, S., Hermann, S., Jost, R., König, A., Liss, T., Lüßmann, R., May, M., Nonhoff, B., Reichel, B., Strehlow, R., Stamatakis, A., Stuckmann, N., Vilbig, A., Lenke, M., Ludwig, T., Bode, A., and Schleifer, K.-H.: ARB: a software environment for sequence data, Nucleic Acids Res., 32, 1363-1371, 2004.

Mehra, O. P. and Jackson, M. L.: Iron oxide removal from soils and clays by dithionite-citrate systems buffered with sodium bicarbonate, Clay. Clay Miner., 7, 317-327, 1960.

Metje, M. and Frenzel, P.: The effect of temperature on anaerobic ethanol oxidation and methanogenesis in an acidic peat from a northern wetland, Appl. Environ. Microb., 71, 8191-8200, 2005.

Metje, M. and Frenzel, P.: Methanogenesis and methanogenic pathways in a peat from subarctic permafrost, Environ. Microbiol., 9, 954-964, 2007.

Muyzer, G., Hottenträger, S., Teske, A., and Waver, C.: Denaturing gradient gel electrophoresis of PCR amplified 16S rDNA - a new molecular approach to analyse the genetic diversity of mixed microbial communities, in: Molecular Microbial Ecology Manual, edited by: Akkermanns, A. D. L., Van Elsas, J. D., and de Bruijn, F.-J., Kluwer Academic Publishers, Dordrecht, The Netherlands, 1995.

North, N. N., Dollhopf, S. L., Petrie, L., Istok, J. D., Balkwill, D. L., and Kostka, J. E.: Change in bacterial community structure during in situ biostimulation of subsurface sediment cocontaminated with uranium and nitrate, Appl. Environ. Microb., 70, 4911-4920, 2004.

Paul, S., Küsel, K., and Alewell, C.: Reduction processes in temperate forests: tracking down heterogeneity with a combination of methods, Soil Biol. Biogeochem., 38, 1028-1039, 2006.

Petrie, L., North, N. N., Dollhopf, S. L., Blackwill, D. L., and Kostka, J. E.: Enumeration and characterization of iron(III)reducing microbial communities from acidic subsurface sediments contaminated with uranium(VI), Appl. Environ. Microb., 69, 7467-7479, 2003.

Postma, D. and Jakobsen, R.: Redox zonation: Equilibrium constraints on the $\mathrm{Fe}(\mathrm{III}) / \mathrm{SO}_{4}$-reduction interface, Geochim. Cosmochim. Ac., 60, 3169-3175, 1996.

Roden, E. E.: Diversion of electron flow from methanogenesis to crystalline $\mathrm{Fe}(\mathrm{III})$ oxide reduction in carbon-limited cultures of wetland sediment microorganisms, Appl. Environ. Microb., 59, 5702-5706, 2003. 
Roden, E. E. and Wetzel, R. G.: Organic carbon oxidation and suppression of methane production by microbial Fe(III) oxide reduction in vegetated and unvegetated freshwater wetland sediments, Limnol. Oceanogr., 4, 1733-1748, 1996.

Roden, E. E. and Wetzel, R. G.: Competition between Fe(III)reducing and methanogenic bacteria for acetate in iron-rich freshwater wetland sediments, Microb. Ecol., 45, 252-258, 2003.

Roden, E. E., Sobolev, D., Glazer, B., and Luther III, G. W.: Potential for microscale bacterial Fe redox cycling at the aerobicanaerobic interface, Geomicrobiol. J., 21, 379-391, 2004.

Schmalenberger, A., Drake, H. L., and Küsel, K.: High unique diversity of sulfate-reducing prokaryotes in a depth gradient in an acidic fen, Environ. Microbiol., 9, 1317-1328, 2007.

Schmalenberger, A., Tebbe, C. C., Kertesz, M. A., Drake, H. L., and Küsel, K.: Two-dimensional single strand conformation polymorphism (SSCP) of 16S rRNA gene fragments reveals highly dissimilar bacterial communities in an acidic fen, Eur. J. Soil Biol., in press, 2008.

Schwertmann, U.: Differenzierung der Eisenoxide des Bodens durch Extraktion mit saurer Ammoniumoxalat-Lösung, Z. Pflanzenern. Düng. Bodenk., 105, 194-202, 1964.

Shannon, R. D. and White, J. R.: The effects of spatial and temporal variations in acetate and sulfate on methane cycling in two Michigan peats, Limnol. Oceanogr., 41, 435-443, 1996.

Singleton, D. R., Furlong, M. A., Rathbun, S. L., and Whitman, W. B.: Quantitative comparisons of 16S rRNA gene sequence libraries from environmental samples, Appl. Environ. Microb. 67, 4374-4376, 2001.

Snoeyenbos-West, O. L., Nevin, K. P., Anderson, R. T., and Lovley, D. R.: Enrichment of Geobacter species in response to stimulation of $\mathrm{Fe}(\mathrm{III})$ reduction in sandy aquifer sediments, Microb. Ecol., 39, 153-167, 2000.

Straub, K. L. and Buchholz-Cleven, B. E. E.: Geobacter bremensis sp. nov. and Geobacter pelophilus sp. nov., two dissimilatory ferric-iron-reducing bacteria, Int. J. Syst. Evol. Micr., 51, 18051808, 2001.

Straub, K. L., Benz, M., and Schink, B.: Iron metabolism in anoxic environments at near neutral pH, FEMS Microbiol. Ecol., 34, 181-186, 2001.

Tamura, H., Goto, K., Yotsuyanagi, T., and Nagayam, M.: Spectrophotometric determination of iron(II) with 1,10-phenantroline in the presence of large amounts of iron (III), Talanta, 21, 314$318,1974$.
Todorova, S. G., Siegel, D. I., and Costello, O. M.: Microbial Fe(III) reduction in a minerotrophic wetland - geochemical controls and involvement in organic matter decomposition, Appl. Geochem., 20, 1120-1130, 2005.

Van Bodegom, P. M., Scholten, J. C. M., and Stams, A. J. M.: Direct inhibition of methanogenesis by ferric iron, FEMS Microbiol. Ecol., 49, 261-268, 2004.

Verville, J. H., Hobbie, J. E., Chapin, F. S. I., and Hooper, D. U.: Response of tundra $\mathrm{CH}_{4}$ and $\mathrm{CO}_{2}$ flux to manipulation of temperature and vegetation, Biogeochemistry, 41, 215-235, 1998.

Vile, M. A. and Wieder, R. K., Alkalinity generation by Fe (III) reduction versus sulfate reduction in wetlands constructed for acid mine drainage treatment, Water Air Soil Poll., 69, 425-441, 1993.

Vile, M. A., Bridgham, S. D., Novak, M., and Wieder, R. K.: Atmospheric sulfur deposition alters pathways of gaseous carbon production in peatlands, Global Biogeochem. Cy., 17(2), 1058, doi:10.1029/2002GB001966, 2003.

Wieder, R. K. and Lang, G., Cycling of inorganic and organic sulfur in peat from Big Run Bog, West Virginia, Biogeochemistry, 5, 221-242, 1988.

Wieder, R. K., Yavitt, J. B., and Lang, G. E.: Methane production and sulfate reduction in two Appalachian peatlands, Biogeochemistry, 10, 81-104, 1990.

Williams, R. T. and Crawford, R. L.: Methane production in Minnesota peatlands, Appl. Environ. Microb., 47, 1266-1271, 1984.

Wu, Q., Sanford, R. A., and Loffler, F. E.: Uranium(VI) reduction by Anaeromyxobacter dehalogenans strain 2CP-C, Appl. Environ. Microb., 72, 3608-3614, 2006.

Wuebbles, D. J. and Hayhoe, K.: Atmospheric methane and global change, Earth-Sci. Rev., 57, 177-210, 2002.

Wulf-Durand, P., Bryant, L. J., and Sly, L. I.: PCR-mediated detection of acidophilic, bioleaching-associated bacteria, Appl. Environ. Microb., 63, 2944-2948, 1997.

Zehnder, A. J. B. and Stumm, W.: Geochemistry and biogeochemsitry of anaerobic habitats, in: Biology of Anaerobic Microorganisms, edited by: Zehnder, A. J. B., John Wiley \& Sons Inc., New York, 1-38, 1988. 